The mast cells are initial effective lineage in both humoral and adaptive immunity. They are ubiquitous in skin, mucosa, and in function. They contain biologically essential and dynamic mediators in healthy and harmful conditions of tissue. Mast cell malfunctioning could be attributed to various chronic allergic diseases. Considerately, emerging evidence of mast cell involvement in various cancers shows them to have both positive and negative roles in tumour growth. It mostly indulges in tumour progression and metastasis via angiogenesis, extracellular matrix degradation, and mitogenic activity in the tumour microenvironment. The current paper reviewed research papers on mast cells in oral squamous cell carcinoma through the PubMed database from 1980 to the present date. The present paper is an attempt to summarise the research reports on the role of mast cells in oral squamous cell carcinoma. Further to this note, this paper also outlines the role of mast cells in normal physiological processes and tumour biology.

Key words: mast cells, tryptase, angiogenesis, mediators, chymase, histamine, oral squamous cell carcinoma.

Contemp Oncol (Pozn) 2017; 21 (1): 21-29 DOI: https://doi.org/10.5114/wo.2017.65157

\section{The role of mast cells in oral squamous cell carcinoma}

\author{
Swetha Gudiseva ${ }^{1}$, Arvind Babu Rajendra Santosh ${ }^{2}$, Raviteja Chitturi ${ }^{3}$, \\ Vamsikrishna Anumula ${ }^{4}$, Chandrashekar Poosarla ${ }^{1}$, \\ Venkat Ramana Reddy Baddam ${ }^{1}$
}

${ }^{1}$ Department of Oral Pathology and Microbiology, SIBAR Institute of Dental Sciences, Guntur, Andhra Pradesh, India

2Dentistry Programme, Faculty of Medical Sciences, The University of the West Indies, Mona campus, Kingston, Jamaica, West Indies

${ }^{3}$ School of Dentistry, University of the West Indies, St. Augustine, Trinidad and Tobago, West Indies

${ }^{4}$ Department of Pedodontics and Preventive dentistry, Krishna devaraya Institute of Dental Sciences, Bangalore, Karnataka, India

\section{Introduction}

Mast cells form a component of the immune system playing an important role in host defence. They reside in all the vascularised tissues, especially in all the connective tissues and mucosal surfaces of the human body, but mature cells cannot be identified in the circulation [1]. They are mobile and contain numerous granules, derived from haemopoietic progenitor cells, which emanate to the tissues to stanch as progenitor cells. They are also known as mastocyte or as labrocyte, derived from the Latin word mastocytus [2], mast meaning "well fed" or "fattening" in German. It was first described by Paul Ehrlich in 1878 as cells belonging to the connective tissue staining purple to blue with aniline blue dye due to the presence of an abundant number of granules [1]. The morphology and cytogenicity of the mast cells differs according to the tissue and hence can be differentiated by staining for their contents [3]. The strategic role of these cells was in mediating type 1 hypersensitivity reaction, acting as effector cells in IgE-mediated host immune responses. They are activated by diverse mechanisms and hence secrete their products, thus playing an important role in sustaining health or backing to disease. They have been found to be significantly associated with increased mitotic activity, extracellular matrix degradation, angiogenesis, intensification of microvascular hyper permeability, and recruitment of inflammatory cells including macrophages [4].

\section{Material and methods}

A literature search for mast cell-related oral squamous cell carcinoma was conducted in the PubMed database using related Medical Subject Heading (MeSH) terms: "Mast cell and Oral cancer" and "Mast cell and Oral Squamous Cell Carcinoma". From the late 1980s until the present, forty-five research papers have been published in the PubMed database. The research papers were included based on the following: (1) full-text availability; (2) research papers that were available in English language, and (3) papers having information on mast cell in oral cancer and oral squamous cell carcinoma. Research papers were excluded based on: (1) duplication of the titles, (2) mast cell research on non-oral tissue site of squamous cell carcinoma, and (3) research papers that had an incorrect web-link for full text accessibility. Twenty-three articles were excluded based on the inclusion and exclusion criteria of the study. Finally, twenty-two research papers were included in the present study to summarise the report on the role of mast cells in oral squamous cell carcinoma. 


\section{Mast cell biology in physiological conditions}

Mast cells, in both morphology and function, resemble basophils. Initially they were thought to be basophils that reside in the tissue, but later they were identified as separate entities due to their development from different haematopoietic lineages [5]. The similarities between them are as follows: both secrete granules containing heparin and histamine, express high affinity receptor for IgE Fc RI under latent conditions, the method of degranulation, and the common precursor positivity for CD34 [6]. The features that distinguish them are as follows: basophils that are bi-lobed leave the bone marrow after maturation, and in case of mast cells having single rounded nuclei they circulate in an immature form and then mature at the proper tissue site. Basophils are not seen in normal tissue but can be seen at a local site due to stimulation by cytokines released from mast cells or T cells. In contrast, mast cells cannot be identified in circulation but can be seen in tissues. The major component of the granules of mast cells and basophils are heparin and chondroitin sulphate, respectively [7].

\section{Types}

They are tissue resident sentinel cells and are divided into two types based on the substances present in their granules. They have been identified as connective tissue mast cells and mucosal mast cells. The granules secreted by the mast cells have been cloned and sequenced to categorise the clear dissimilarities between the two cell types. An abundant amount of chondroitin sulphate, little histamine, the presence of only tryptase $\left(\mathrm{MC}_{\mathrm{T}}\right)$, and absence of chymase are important characteristics of mucosal mast cells. They are found abundantly in intestinal mucosa and alveolar spaces in the lung, ably their incidence is T-cell dependent. Connective tissue mast cells contain several neutral proteases, including tryptase, chymase $\left(\mathrm{MC}_{\mathrm{TC}}\right)$, cathepsin G-like protease, and carboxypeptidase. They are found abundantly in skin, breast, gastrointestinal tract, myocardium, synovium, and conjunctiva and are T-cell independent [3].

Ultra-structurally they are quite large round or ovoid cells that contain abundant membrane-bound granules, about 300 in number per cell. The nucleus is round to oval in shape, which is generally obscured due to their extensive content of electron-dense secretory granules. Irregular outline, numerous mitochondria, prominent Golgi, few smooth endoplasmic reticulum (SER), and some rough endoplasmic reticulum (RER) are a few important findings. In routine $H \& E$ sections they are less noticeable and can be easily missed. Each granule is enclosed by a membrane measuring about 0.2 to 0.8 microns in diameter, which may have electron-dense lamellae, crystalline lattices, or densely packed fine amorphous material [7].

\section{Functional activation}

The chief function of the mast cells is that they participate in innate immunity. They have a wide array of receptors that sense environmental changes and are able to secrete various effector molecules. The effector molecules are stored in the form of granules such as serotonin, histamine, heparin, tryptase, and chymase. The other molecules synthesised de novo upon stimulation are the lipid mediators, certain prostaglandins, and leukotrienes, which are the chemical mediators of inflammation. Biosynthesis of a variety of cytokines that are associated with T-helper 1 (Th1) cells includes interleukin $1 \beta$ (IL1- $\beta$ ), which is important for biosynthesis of angiogenic factors, interleukin (IL-10), and transforming growth factor $\beta$ (TGF- $\beta$ ), which have a role in immunosuppression. The other sub-

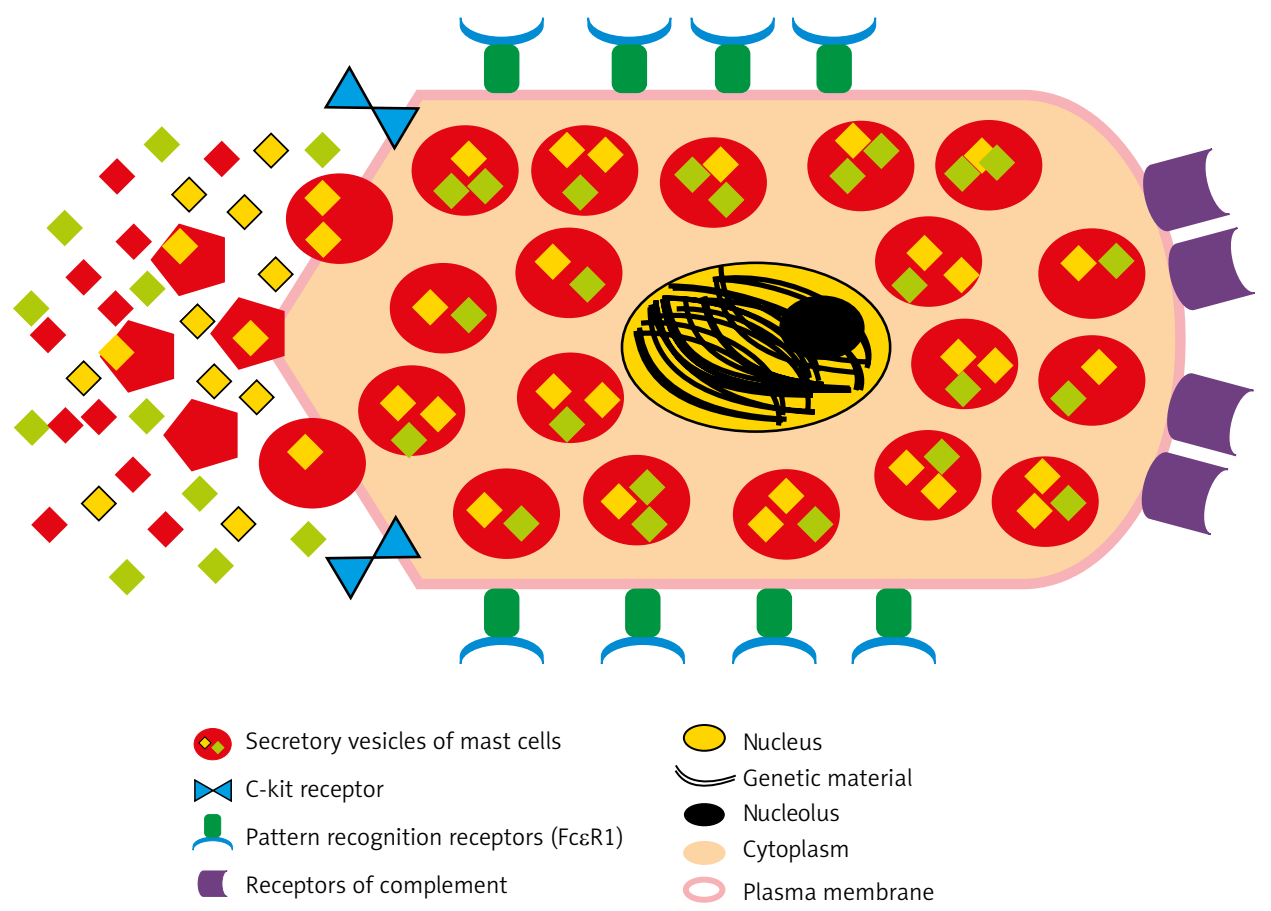

Fig. 1. Mast cells vesicles, granules and receptors 


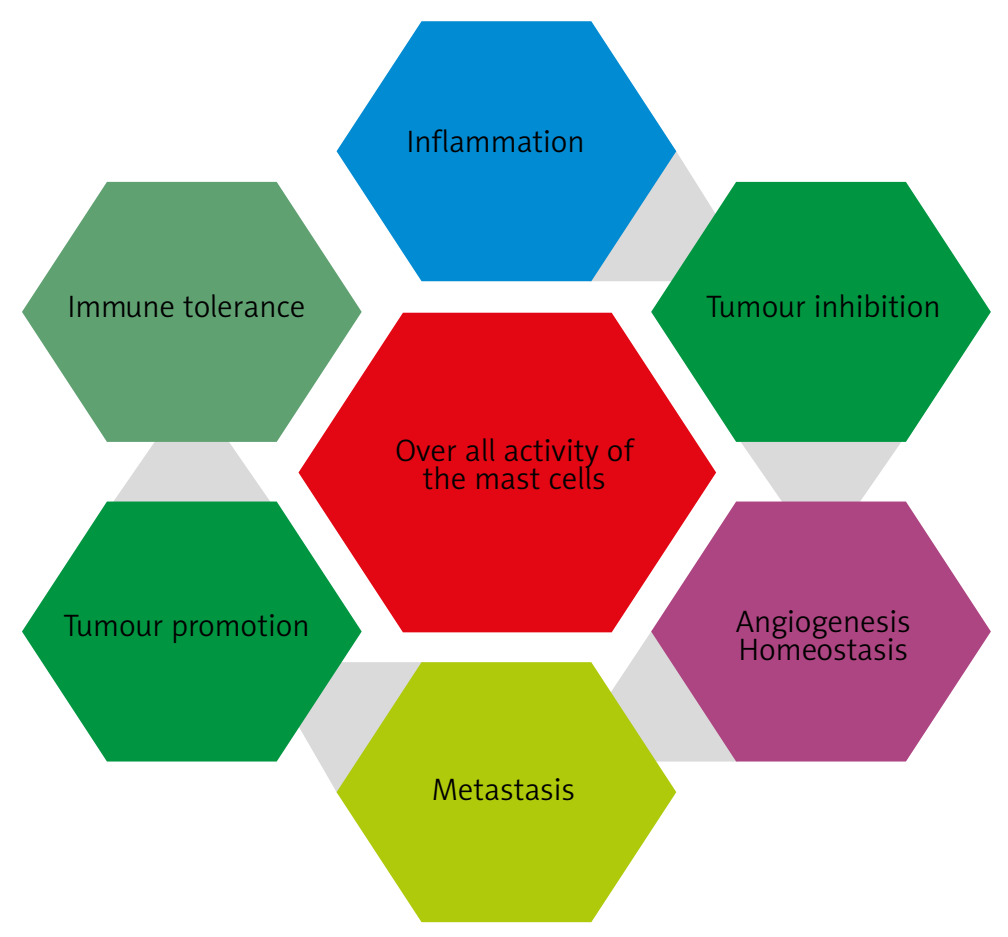

Fig. 2. Over all activity of mast cells

stances produced by mast cells, which deserve attention are the products of cyclooxygenase and lipoxygenase activities that have recently been shown to be a potent intestinal polyposis promoting factor in mice. The action of mast cells and release of all these mediators can occur within minutes of activation or can occur in a delayed fashion (over hours) [8].

Mast cells will be activated classically via IgE receptor whenever a foreign antigen enters into the body by means of different signal transduction pathways through the receptors on its surface $[9,10]$. Neuropeptides, cytokines, growth factors, toxins, complement, lectins, immune complexes, and physical stimuli act as mediators for stimulating the mast cells [11]. Few pathogens like bacteria, viral, and fungal organisms possess pathogen-associated molecular patterns recognised by c-kit, toll like receptors (TLR) 1, 7 and 9, Nod-like receptors, and retinoic acid inducible gene 1 -like receptors on the surface of mast cells [12]. They are activated by crosslinking of Fc\&RI $\alpha$ (FceRI) molecules with antigens bound to respective antibodies.

This entire process is umpired by three mechanisms. Firstly by release of granules - exocytosis - which helps to increase vascular permeability, stimulates smooth muscle contraction, and degrades microbial substances, tissue damage, and remodelling [13] (Fig. 1). The second mechanism is secretion of lipid mediators - performing functions like vasodilatation, bronchoconstriction, neutrophil chemotaxis, mucous secretion, and increasing vascular permeability. The last mechanism is biosynthesis and secretion of cytokines, which promotes mast cell proliferation, inflammation, late phase reaction, Th2 cell differentiation, eosinophil production, and activation. These events in turn will be controlled by different mechanisms. Mast cells cor- respondingly express receptors for numerous components of complement system like CR3, CR4, and CR5 [14].

Nonetheless, it has been observed that mast cells can also be activated via other pathways and extrinsic signals. These 'alternate pathways' are thought to play an important role in infiltration in tumours (Fig. 2). Another important aspect of mast cells recently discovered is their ability to change their phenotype according the site and the duration of stimuli to which they are exposed. This is termed 'mast cell plasticity' $[15,16]$. Mast cells have a long life and form a heterogeneous population of cells that seem to have both a positive and negative regulatory effect on the immune system. They participate in both innate as well as adaptive immunity. The physiological function of mast cells in epithelium, endothelium, and the nervous system is immune modulatory. They are ubiquitous in taking part in maintaining homeostasis of the body $[17,18]$. The mediators induce microbial clearance, debris removal, wound contraction, keratinisation, and proliferation of epithelial cells and fibroblasts. Communication among mast cells and the nervous system ensues through the synaptic-like assemblies via adhesion molecules such as N cadherin or synCAM [4].

\section{The role of mast cells in tumour biology}

The role of mast cells in cancer in still debatable as to whether it helps in tumour progression or has an anti-tumour effect. The principle concept behind its role against tumours is that it is a cell that participates in innate immunity, and it obviously seems to have an anti-tumorigenic effect. However, some authors have proposed that it has a role in progression of tumours. The presence of mast cells in tumours has been found to be an independent prognostic factor and predictor of poor outcome of prostate cancer, mela- 
noma, pancreatic cancer, and leukaemia [19-22]. Increased expression of c-Kit and stem cell factor, which in turn is necessary for the migration, maturation, and survival of mast cells, has been observed in tumours of the breast [23].

Other than this increased mast cells count and infiltration of mast cells in the stroma have been associated with Merkel cell carcinoma, lung cancer, hepatocellular carcinoma, colorectal cancer, and Hodgkin's and follicular lymphoma [24]. As far as oral squamous cell carcinoma (OSCC) is concerned, it has been observed that there are increased microvessel density and increased mast cell density in OSCC, which can be a reason for poor prognosis $[25,26]$. The tumour promotion by mast cells is principally considered to be due to its angiogenic ability. Evidence of degranulation and angiogenesis due to mast cells in pre-malignancy has also been observed in various mouse model studies. Takuji et al. reported an increase in mast cell density, and infiltration into the tumour site was evident, in mice colonic carcinoma (azoxymethane and dextran sodium sulphate induced). There was a significant increase in its presence in the dysplastic lesional areas to carcinomas. Tumour necrosis factor $\alpha$ (TNF- $\alpha$ ) is one of the important tumour progression molecules secreted by mast cells at the tumour site [27].

Mast cells can also modulate haemostasis and blood perfusion in tumours by production of heparin, which acts as an anticoagulant [28]. The other possible methods in which mast cells promote tumours is by their mitogenic ability, deletion of tumour suppressor genes, and activation of certain oncogenes via the c-kit locus [29]. The secretion of proteases, which contributes to extracellular matrix degradation, formation of vascular tube, release of trapped angiogenic factors, and promotion of metastasis is possibly another mechanism by which mast cells promote the tumours [30]. Johansson et al. suggested that orthotopic mouse models showed activity of peri-tumoural mast cells, which increase angiogenic activity with significant expression of fibroblast growth factor-2, simulating the growth of prostate tumours [31]. Chang et al. utilised the K-ras transgenic spontaneous mouse model to demonstrate early infiltration mast cells in the pancreatic ductal adenocarcinoma, which mimic the tumorigenesis as in humans, and correlated the poor prognosis in pancreatic tumours [32].

The interaction between cancer cells and their microenvironment is very important to both tumour progression and the arrest of its growth. The mast cells have been found to have both direct mitogenic activities on tumour cells as well as an indirect effect on the microenvironment by promoting its invasive potential. This is brought about mainly by heparin and TNF- $\alpha[32,33]$. Much less has been said about the ability of mast cells to promote the immune response against tumour growth, although it is well known that mast cells are antigen presenting cells and they promote migration, maturation, and function of dendritic cells, which interact with T and B cells [34].

Many studies were conducted on mast cell association with cancer to state its accumulation in and around the tissue [35]. Mast cells play an important role by liberating heady pro-angiogenic and angiogenic factors, which aids in tumour interaction with the host, thus supporting tumour progression. Not only was its involvement in tumour progression identified, but also progression of leukoplakia with and without dysplasia to oral squamous cell carcinoma was established. The main factors released are heparin, histamine, chymase, tryptase, basic fibroblast growth factor (bFGF), vascular endothelial growth factor (VEGF), and TGF- $\beta$ [4]. Epidermal keratinocytes and endothelial cells secrete mast cell growth factor, which aids the migration of the mast cells and moreover the homing of mast cell pioneers to the epithelial tissues. Calcitonin gene-related peptide and substance $p$ helps in degranulation of mast cells to release its products favouring tumour progression [36]. Copious mast cells are seen at the tumour periphery and are involved in the breakdown of collagenous matrix by provoking fibroblasts to yield excess amounts of collagenase [37].

Tryptase helps in the process of neovascularisation by increasing the number of fibroblasts and matrix reorganisations with type $\alpha 1$ procollagen mRNA. Chymase both directly and indirectly stimulates progelatinase $B$, which causes proteolysis of extracellular matrix emancipating angiogenic factor VEGF, TNF- $\alpha$, heparanase, angiopontin 1 , IL-18, and FGF. Cytokines especially IL-8 produced by mast cells induce matrix metalloproteinase 2 (MMP-2) facilitating endothelial cell migration assisting angiogenesis. A greater number of mast cells are found with increased number of micro vessels and direct relation of mast cells was found with vascular tube formation [37]. It has the capacity to respond to certain signal transduction pathways thus providing signals by release of mediators like FGF 2 , which increases the mitotic activity of the tumour cells. They also secrete TNF- $\alpha$, which has been implicated in increased expression of MMP-2, MMP-9, and chops type IV collagen helping in invasion [38] (Fig. 3).

Michailidou et al. mentioned that the presence of mast cells has been correlated with a better prognosis of cancers. Anticancer effects have been found in very few tumours, especially breast cancers. The antitumor effects of mast cells include inhibition of cell growth, amplified inflammatory antitumor response, and they also help in secreting substances that decrease tumour cell motility. Prostacyclin-synthase, which is secreted by the endothelial cells in response to histamine produced by mast cells, eosinophil recruitment, and survival promoted by mast cell tryptase and IL-5, acts as a factor of tumour regression [4].

Hence, in the process of cancer, mast cells play an important role in tumour progression, cell proliferation, angiogenesis, extracellular matrix degradation, and hence in invasion and metastasis [4]. Until recently, the role of mast cells has been ignored in cancer. Studies, being conducted have revealed that they play a significant role in the progression of cancer [39]. Thus it can be said that targeting the survival/function of mast cells can easily influence the behaviour of cancer cells and ultimately its clinical response.

\section{Evidence-based report on the role of mast cells in oral squamous cell carcinoma}

Mast cells originate from haematopoietic precursor cells in bone marrow tissue. Stem cell factor (SCF) is re- 


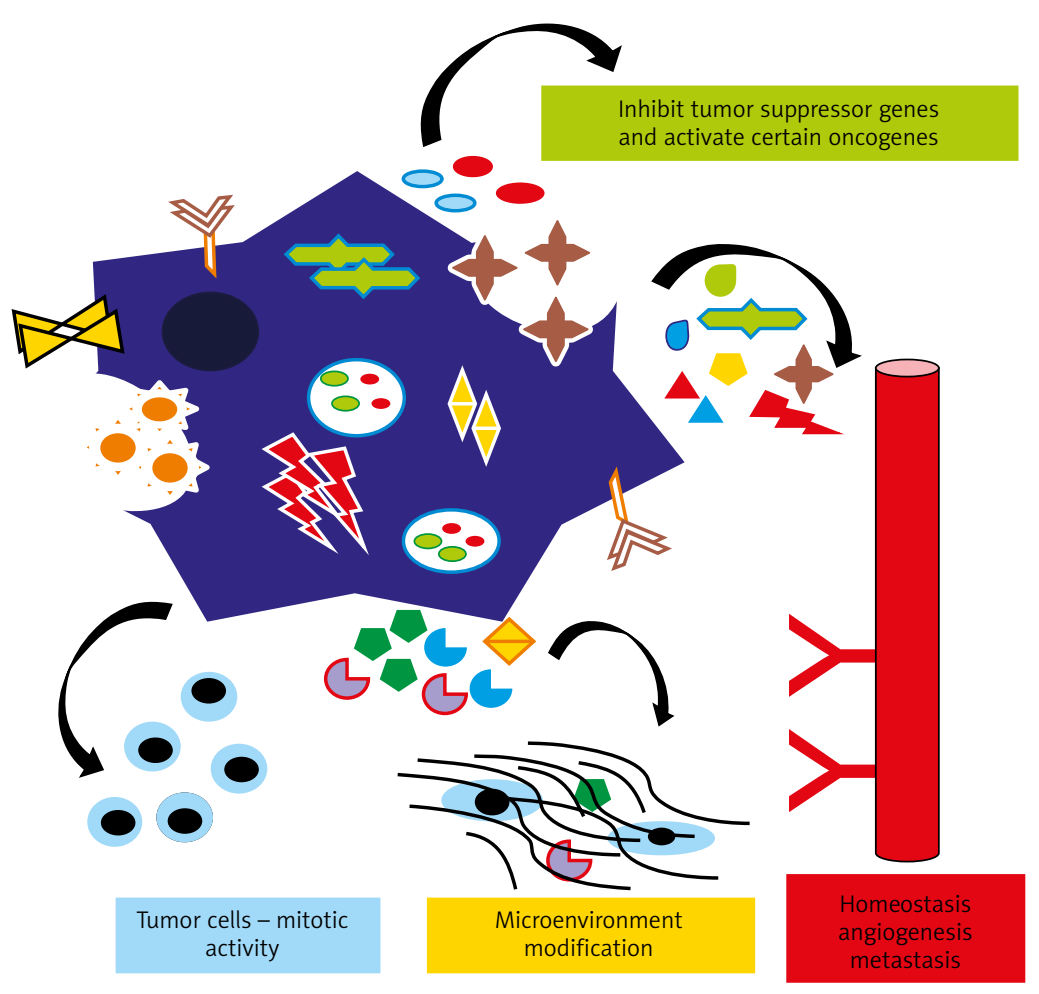

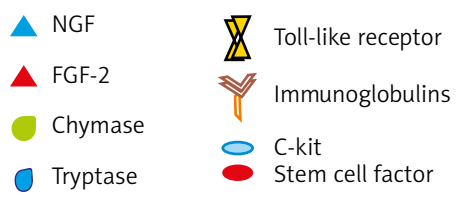

Fig. 3. Mast cell activity in tumour microenvironment

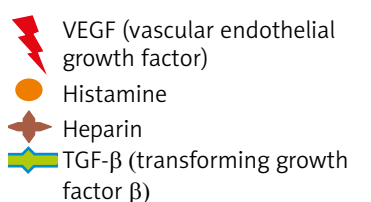

sponsible for migration and circulation into the blood stream, and further entry into distant peripheral tissues [40]. Mast cells that have migrated undergo cellular differentiation and eventually mature in the peripheral tissues. In addition, SCF plays an important role in the survival of mast cells because wells stimulate directional motility of mucosal and connective tissue type of mast cells [41]. Forty-five research studies have been published from the late 1980s until today on mast cell-related oral squamous cell carcinoma research. However, only twenty-two research papers were available as full text in the PubMed database. The results and inference of those full text research studies are summarised in Table 1.

The location of mast cells in the tumour-host tissue interface reveals that it plays an important role in host defence. Mast cells have the ability to retain preformed mediators that can facilitate immune-regulation, matrix degradation, elastic change, and angiogenesis [42]. The mast cell population is triggered in the ultraviolet exposed areas of dermal carcinomas [43]. On the other hand, some studies demonstrated that the presence, density, and activation of mast cells in oral tissue could be influenced by the chemicals in tobacco smoking [44]. The elevated mast cell population in the tissue plays an imperative role in the modification of the microenvironment during oncogenesis. The presence of mast cells near blood vessels sup- ports in neo-angiogenesis, which is mediated by bFGF, TGF, TNF- $\alpha$, tryptase, and heparin [45]. Mast cells were positively correlated with extracellular matrix degradation. The mast cells play a role in the release and biosynthesis of MMP, which can lead to collagen tissue degradation [46].

The mast cell population is significantly elevated in oral epithelial dysplasia and oral squamous cell carcinomatous conditions [47-51]. Investigations suggest that the mast cell population is significantly more increased in oral squamous cell carcinomas than in oral epithelial dysplasia [52]. The increase in mast cell population is significantly positive in tumour front as well as intralesional areas of well differentiated oral squamous cell carcinomas compared to moderately or poorly differentiated oral squamous cell carcinoma $[53,54]$. On the other hand, a study has shown that there is no significant increase among well, moderate, or poorly differentiated squamous cell carcinoma [49]. The mast cell population is significantly increased in advanced stages of epithelial dysplasia and oral submucous fibrosis [55]. A molecular epidemiological study on mast cell population revealed a significantly higher number of mast cells in squamous cell carcinoma of skin than oral mucosa. Furthermore, the mast cell population was higher in squamous cell carcinoma of the lip than oral mucosal epithelium. Another study showed that the increase in mast cell population 
Table 1. Reported mast cell-related oral squamous cell carcinoma research

\begin{tabular}{|c|c|c|c|c|}
\hline $\begin{array}{l}\text { Area of } \\
\text { mast cell } \\
\text { related OSCC } \\
\text { research }\end{array}$ & Study hypothesis & $\begin{array}{l}\text { Area of } \\
\text { mast cell } \\
\text { related OSCC } \\
\text { research }\end{array}$ & Study inference & $\begin{array}{l}\text { Authors/ } \\
\text { Year }\end{array}$ \\
\hline $\begin{array}{l}\text { Molecular } \\
\text { epidemiology } \\
\text { of mast cell } \\
\text { population }\end{array}$ & $\begin{array}{l}\text { Compare the number, } \\
\text { and morphological and } \\
\text { topographical distribution of } \\
\text { mast cells in oral epithelial } \\
\text { dysplasia, oral sub mucus } \\
\text { fibrosis, and oral squamous cell } \\
\text { carcinoma and correlate with } \\
\text { inflammatory cell infiltrate }\end{array}$ & $\begin{array}{l}\text { Molecular } \\
\text { epidemiology } \\
\text { of mast cell } \\
\text { population }\end{array}$ & $\begin{array}{l}\text { Increased proliferation of mast cells was observed } \\
\text { in oral squamous cell carcinoma compared to oral } \\
\text { epithelial dysplastic tissues and oral sub mucus } \\
\text { fibrosis. } \\
\text { Atypical mast cell proliferation was observed in } \\
\text { moderately inflamed oral squamous cell carcinoma } \\
\text { tissues. Whereas, granular mast cell proliferation } \\
\text { was observed in severely inflamed oral squamous } \\
\text { cell carcinoma tissues }\end{array}$ & $\begin{array}{l}\text { Telagi } \\
\text { et al. } 2015 \\
{[47]}\end{array}$ \\
\hline $\begin{array}{l}\text { Molecular } \\
\text { epidemiology } \\
\text { of mast cell } \\
\text { population }\end{array}$ & $\begin{array}{l}\text { Evaluate the distribution of } \\
\text { mast cell population in normal } \\
\text { oral mucosa and oral squamous } \\
\text { cell carcinoma }\end{array}$ & $\begin{array}{l}\text { Molecular } \\
\text { epidemiology } \\
\text { of mast cell } \\
\text { population }\end{array}$ & $\begin{array}{l}\text { Increased expression of mast cell and degranulated } \\
\text { mast cell population was observed in oral squamous } \\
\text { cell carcinoma, and it was statistically significant }\end{array}$ & $\begin{array}{l}\text { Zaidi et al. } \\
2014 \text { [48] }\end{array}$ \\
\hline $\begin{array}{l}\text { Molecular } \\
\text { epidemiology } \\
\text { of mast cell } \\
\text { population }\end{array}$ & $\begin{array}{l}\text { Estimate and compare the } \\
\text { quantitative distribution of } \\
\text { mast cell population in normal } \\
\text { mucosa and oral squamous cell } \\
\text { carcinoma }\end{array}$ & $\begin{array}{l}\text { Molecular } \\
\text { epidemiology } \\
\text { of mast cell } \\
\text { population }\end{array}$ & $\begin{array}{l}\text { Three-fold increase of mast cell distribution in } \\
\text { the oral squamous cell carcinoma tissue while } \\
\text { comparing with normal mucosa. However, no } \\
\text { statistical significance was found while comparing } \\
\text { the distribution of mast cell population among well, } \\
\text { moderate, and poorly differentiated types }\end{array}$ & $\begin{array}{l}\text { Anuradha } \\
\text { et al. } 2014 \\
{[49]}\end{array}$ \\
\hline $\begin{array}{l}\text { Molecular } \\
\text { epidemiology } \\
\text { of mast cell } \\
\text { population }\end{array}$ & $\begin{array}{l}\text { To evaluate the distribution of } \\
\text { mast cell tryptase and mast cell } \\
\text { chymase in Oral submucous } \\
\text { fibrosis and oral squamous cell } \\
\text { carcinoma }\end{array}$ & $\begin{array}{l}\text { Molecular } \\
\text { epidemiology } \\
\text { of mast cell } \\
\text { population }\end{array}$ & $\begin{array}{l}\text { Statistically significant increase in mast cell } \\
\text { chymase concentration in oral squamous cell } \\
\text { carcinoma. Whereas, oral submucous fibrosis tissue } \\
\text { showed statistically significant decreased presence } \\
\text { of mast cell chymase concentration. } \\
\text { Mast cell tryptase concentration was increased in } \\
\text { both oral squamous cell carcinoma and advanced } \\
\text { oral submucous fibrosis }\end{array}$ & $\begin{array}{l}\text { Yadav et al. } \\
2014 \text { [50] }\end{array}$ \\
\hline $\begin{array}{l}\text { Mast cell and } \\
\text { angiogenesis }\end{array}$ & $\begin{array}{l}\text { To evaluate mast cell } \\
\text { concentration and microvessel } \\
\text { density in perilesional and } \\
\text { intra-lesional regions of oral } \\
\text { squamous cell carcinoma }\end{array}$ & $\begin{array}{l}\text { Mast cell and } \\
\text { angiogenesis }\end{array}$ & $\begin{array}{l}\text { Increased microvessel density and mast cell } \\
\text { concentration was observed in both peri- and intra- } \\
\text { lesional regions of oral squamous cell carcinoma. } \\
\text { In addition, statistically significant positive } \\
\text { correlation between microvessel density and mast } \\
\text { cell concentration was observed in both peri- } \\
\text { and intra-lesional regions of oral squamous cell } \\
\text { carcinoma tissues }\end{array}$ & $\begin{array}{l}\text { Pyziak } \\
\text { et al. } 2013 \\
{[51]}\end{array}$ \\
\hline $\begin{array}{l}\text { Molecular } \\
\text { epidemiology } \\
\text { of mast cell } \\
\text { population }\end{array}$ & $\begin{array}{l}\text { Quantitative comparison of } \\
\text { mast cell density in normal oral } \\
\text { mucosa, actinic cheilitis, and lip } \\
\text { squamous cell carcinoma }\end{array}$ & $\begin{array}{l}\text { Molecular } \\
\text { epidemiology } \\
\text { of mast cell } \\
\text { population }\end{array}$ & $\begin{array}{l}\text { Increased mast cell density was observed in oral } \\
\text { submucous fibrosis and actinic cheilitis (with mild } \\
\text { and severe epithelial dysplasia) than normal oral } \\
\text { mucosa }\end{array}$ & $\begin{array}{l}\text { Gomes } \\
\text { et al. } 2008 \\
{[52]}\end{array}$ \\
\hline $\begin{array}{l}\text { Mast cell and } \\
\text { angiogenesis }\end{array}$ & $\begin{array}{l}\text { Correlation of blood vessel } \\
\text { and mast cell density in } \\
\text { well, moderately, and poorly } \\
\text { differentiated squamous cell } \\
\text { carcinoma }\end{array}$ & $\begin{array}{l}\text { Mast cell and } \\
\text { angiogenesis }\end{array}$ & $\begin{array}{l}\text { Mast cell and blood vessel density are significantly } \\
\text { increased in Oral squamous cell carcinoma tissue. } \\
\text { In addition, correlation of mast cell proliferation and } \\
\text { blood vessel density was statistically significant in } \\
\text { well differentiated squamous cell carcinoma but not } \\
\text { in moderately and poorly differentiated types }\end{array}$ & $\begin{array}{l}\text { Kathuriya } \\
\text { et al. } 2015 \\
{[53]}\end{array}$ \\
\hline $\begin{array}{l}\text { Molecular } \\
\text { epidemiology } \\
\text { of mast cell } \\
\text { population }\end{array}$ & $\begin{array}{l}\text { To compare the mast cell } \\
\text { density in various grades of oral } \\
\text { squamous cell carcinoma and } \\
\text { normal oral mucosa }\end{array}$ & $\begin{array}{l}\text { Molecular } \\
\text { epidemiology } \\
\text { of mast cell } \\
\text { population }\end{array}$ & $\begin{array}{l}\text { Mast cell density was significantly higher in well } \\
\text { differentiated squamous cell carcinoma than in } \\
\text { other histological types. The mast cell density was } \\
\text { significantly reduced in poorly differentiated variant }\end{array}$ & $\begin{array}{l}\text { Vineet } \\
\text { et al. } 2012 \\
\text { [54] }\end{array}$ \\
\hline $\begin{array}{l}\text { Molecular } \\
\text { epidemiology } \\
\text { of mast cell } \\
\text { population }\end{array}$ & $\begin{array}{l}\text { Distribution of mast cell density } \\
\text { in oral submucous fibrosis } \\
\text { tissues }\end{array}$ & $\begin{array}{l}\text { Molecular } \\
\text { epidemiology } \\
\text { of mast cell } \\
\text { population }\end{array}$ & $\begin{array}{l}\text { Increased prevalence of mast cell density was } \\
\text { observed in all the stages of oral submucous } \\
\text { fibrosis. However, statistically significant increased } \\
\text { proliferation was observed in advanced stages of } \\
\text { oral submucous fibrosis than in early stage of lesion }\end{array}$ & $\begin{array}{l}\text { Pujari } \\
\text { et al. } 2013 \\
{[55]}\end{array}$ \\
\hline $\begin{array}{l}\text { Molecular } \\
\text { epidemiology } \\
\text { of mast cell } \\
\text { population }\end{array}$ & $\begin{array}{l}\text { Compare the concentration } \\
\text { of mast cells in squamous cell } \\
\text { carcinoma and oral cavity }\end{array}$ & $\begin{array}{l}\text { Molecular } \\
\text { epidemiology } \\
\text { of mast cell } \\
\text { population }\end{array}$ & $\begin{array}{l}\text { Concentration of mast cells was significantly } \\
\text { lower in squamous cell carcinoma of the mouth } \\
\text { except when the lesion was located on lip. The } \\
\text { concentration of mast cells was unrelated to the } \\
\text { degree of differentiation of the tumour }\end{array}$ & $\begin{array}{l}\text { Parizi } \\
\text { et al. } 2010 \\
{[56]}\end{array}$ \\
\hline
\end{tabular}


Table 1. Cont.

\begin{tabular}{|c|c|c|c|c|}
\hline $\begin{array}{l}\text { Area of } \\
\text { mast cell } \\
\text { related OSCC } \\
\text { research }\end{array}$ & Study hypothesis & $\begin{array}{l}\text { Area of } \\
\text { mast cell } \\
\text { related OSCC } \\
\text { research }\end{array}$ & Study inference & $\begin{array}{l}\text { Authors/ } \\
\text { Year }\end{array}$ \\
\hline $\begin{array}{l}\text { Molecular } \\
\text { epidemiology } \\
\text { of mast cell } \\
\text { population } \\
\text { and matrix } \\
\text { degradation }\end{array}$ & $\begin{array}{l}\text { Evaluate mast cell tryptase } \\
\text { levels in oral squamous cell } \\
\text { carcinoma patient serum and } \\
\text { compare with normal healthy } \\
\text { person }\end{array}$ & $\begin{array}{l}\text { Molecular } \\
\text { epidemiology } \\
\text { of mast cell } \\
\text { population } \\
\text { and matrix } \\
\text { degradation }\end{array}$ & $\begin{array}{l}\text { The serum levels of mast cell tryptase were higher } \\
\text { in serum samples of oral squamous cell carcinoma } \\
\text { patients, but it was not statistically significant. } \\
\text { In addition, there was no statistically significant } \\
\text { correlation between serum mast cell tryptase } \\
\text { levels and tumour stage, nodal involvement, and } \\
\text { metastasis }\end{array}$ & $\begin{array}{l}\text { Jaafari et al. } \\
2013 \text { [57] }\end{array}$ \\
\hline $\begin{array}{l}\text { Mast cell and } \\
\text { angiogenesis }\end{array}$ & $\begin{array}{l}\text { Compare mast cell density } \\
\text { with microvascular density } \\
\text { to correlate with angiogenic } \\
\text { activity in various grades of oral } \\
\text { squamous cell carcinomas }\end{array}$ & $\begin{array}{l}\text { Mast cell and } \\
\text { angiogenesis }\end{array}$ & $\begin{array}{l}\text { The densities of mast cells and microvessels were } \\
\text { significantly higher in all grades of oral squamous } \\
\text { cell carcinoma. The densities of mast cells and } \\
\text { micro vessel were significantly higher in moderately } \\
\text { differentiated than in well and poorly differentiated } \\
\text { tumours. There was a positive correlation between } \\
\text { micro vessel and mast cell density and indicate } \\
\text { that mast cell have a role in up-regulation of } \\
\text { angiogenesis in oral squamous cell carcinoma }\end{array}$ & $\begin{array}{l}\text { Sharma } \\
\text { et al. } 2010 \\
{[58]}\end{array}$ \\
\hline $\begin{array}{l}\text { Mast cell and } \\
\text { angiogenesis }\end{array}$ & $\begin{array}{l}\text { To evaluate microvessel and } \\
\text { mast cell density in normal oral } \\
\text { mucosa and oral squamous } \\
\text { cell carcinoma. To correlate } \\
\text { the microvessel and mast cell } \\
\text { density with angiogenesis }\end{array}$ & $\begin{array}{l}\text { Mast cell and } \\
\text { angiogenesis }\end{array}$ & $\begin{array}{l}\text { Both mast cell and microvessel density were } \\
\text { significantly higher in oral squamous cell carcinoma } \\
\text { than normal oral mucosa. } \\
\text { Correlation of microvessel density with mast cell } \\
\text { density was significantly positive in normal oral } \\
\text { mucosa but not in oral squamous cell carcinoma }\end{array}$ & $\begin{array}{l}\text { Jahanshahi } \\
\text { et al. } 2012 \\
{[60]}\end{array}$ \\
\hline $\begin{array}{l}\text { Mast cell and } \\
\text { angiogenesis }\end{array}$ & $\begin{array}{l}\text { To correlate the mast cell } \\
\text { density with angiogenic activity } \\
\text { in oral squamous cell carcinoma }\end{array}$ & $\begin{array}{l}\text { Mast cell and } \\
\text { angiogenesis }\end{array}$ & $\begin{array}{l}\text { Mast cell expressed CD105, VEGF, VEGFR1, and } \\
\text { VEGFR2 both at invasion front and intratumoural } \\
\text { areas of oral squamous cell carcinoma and } \\
\text { positively correlated with tumour angiogenetic } \\
\text { activity }\end{array}$ & $\begin{array}{l}\text { Ciurea et al. } \\
2011 \text { [61] }\end{array}$ \\
\hline $\begin{array}{l}\text { Mast cell and } \\
\text { angiogenesis }\end{array}$ & $\begin{array}{l}\text { Investigate the expression of } \\
\text { three surface markers: CD44, } \\
\text { CD133, and CD117 in oral } \\
\text { squamous cell carcinoma cell } \\
\text { population and to identify their } \\
\text { cancer stem cell population }\end{array}$ & $\begin{array}{l}\text { Mast cell and } \\
\text { angiogenesis }\end{array}$ & $\begin{array}{l}\text { The expression of CD } 133 \text { and CD } 117 \text { at invasion } \\
\text { front and intra-tumoural areas were mast cells } \\
\text { originate. In addition, CD } 44 \text { has limited utility in } \\
\text { identifying cancer stem cell population, and CD } \\
133 \text { and CD } 117 \text { appear to be more limited utility in } \\
\text { identifying cancer stem cell populations }\end{array}$ & $\begin{array}{l}\text { Mărgă- } \\
\text { ritescu } \\
\text { et al. } 2011 \\
{[62]}\end{array}$ \\
\hline $\begin{array}{l}\text { Mast cell } \\
\text { and matrix } \\
\text { degradation }\end{array}$ & $\begin{array}{l}\text { To evaluate mast cell density } \\
\text { and migration and their } \\
\text { association with matrix } \\
\text { metalloproteinase (MMP-9) } \\
\text { expression in squamous cell } \\
\text { carcinoma and actinic cheilitis }\end{array}$ & $\begin{array}{l}\text { Mast cell } \\
\text { and matrix } \\
\text { degradation }\end{array}$ & $\begin{array}{l}\text { Mast cell densities were significantly higher in } \\
\text { squamous cell carcinoma than actinic cheilitis. } \\
\text { Correlation of MMP-9 and mast cell density showed } \\
\text { a strong association in squamous cell carcinoma } \\
\text { progression }\end{array}$ & $\begin{array}{l}\text { Souza et al. } \\
2011 \text { [63] }\end{array}$ \\
\hline $\begin{array}{l}\text { Mast cell and } \\
\text { angiogenesis }\end{array}$ & $\begin{array}{l}\text { Role of mast cells and } \\
\text { angiogenesis in well } \\
\text { differentiated squamous cell } \\
\text { carcinoma }\end{array}$ & $\begin{array}{l}\text { Mast cell and } \\
\text { angiogenesis }\end{array}$ & $\begin{array}{l}\text { Mast cell and microvessel density are significantly } \\
\text { increased in squamous cell carcinoma tissue. } \\
\text { However, correlation of mast cell proliferation with } \\
\text { microvessel density is not statistically significant }\end{array}$ & $\begin{array}{l}\text { Tahir et al. } \\
2013 \text { [64] }\end{array}$ \\
\hline $\begin{array}{l}\text { Mast cell and } \\
\text { angiogenesis }\end{array}$ & $\begin{array}{l}\text { To evaluate angiogenesis, } \\
\text { lymphangiogenesis, and mast } \\
\text { cell density in association with } \\
\text { histological risk assessment } \\
\text { model in oral squamous cell } \\
\text { carcinoma }\end{array}$ & $\begin{array}{l}\text { Mast cell and } \\
\text { angiogenesis }\end{array}$ & $\begin{array}{l}\text { Lymph vessel density showed significant } \\
\text { association with lymphocytic infiltration. However, } \\
\text { mast cell density did not show significant } \\
\text { relationship with histological risk assessment model }\end{array}$ & $\begin{array}{l}\text { Alaeddini } \\
\text { et al. } 2015 \\
\text { [65] }\end{array}$ \\
\hline
\end{tabular}

was unrelated to the degree of differentiation of the tumour [56]. One study showed serum elevation of mast cell tryptase in patients with oral squamous cell carcinoma, but it was not correlated with the staging of cancer (i.e. nodal involvement and metastasis) [57].

Mast cell and microvessel densities are increased in squamous cell carcinoma and indicate that mast cells may play a role in up-regulation of angiogenesis in oral squa- mous cell carcinoma $[41,43,58]$. However, three studies revealed that there is no positive correlation between mast cell density and microvessel density in oral squamous cell carcinoma tissues [42, 58, 64]. On other hand, one study revealed a positive correlation between mast cell and microvessel densities in well differentiated but not in moderately or poorly differentiated types [53]. 
Contrarily, one study observed statistically significant correlation between mast cell and microvessel densities in poorly differentiated OSCC [59]. However, Sharma et al., in 2010, investigated correlation of micro-vascular density with mast cell proliferation and revealed that positive correlation was observed in moderately differentiated lesions but not in well or poorly differentiated types [58]. On the other hand, another study stated that there was significant correlation in mast cell and microvessel density in normal oral mucosa but not in oral squamous cell carcinoma, regardless of the histological grade [60].

However, a recent investigation showed that mast cell in the perilesional and intra tumoural area of oral squamous cell carcinoma expresses CD105, VEGF, VEGFR1, and VEGFR2 and showed positive correlation with angiogenic activity of the tumour [61]. It also stated a mast cell influence on tumour progression and growth [61]. A recent study investigated cancer stem cell population that expresses CD44, CD133, and CD117 at the invasion front and intra-tumoural areas. Their results suggest that CD 133and CD117-positive cells were of mast cell origin and could influence angiogenic activity In addition, CD44 has limited utility in identifying cancer stem cell populations, whereas CD133 and 117 appear to be of more limited utility in identifying cancer stem cell populations [62]. Only one study showed that mast cell and MMP-9 densities were positively correlated in oral squamous cell carcinoma and actinic cheilitis. The increase in mast cell density showed an association with tumour progression in OSCC [63]. Mast cell and lymph vessel density were strongly associated in oral squamous cell carcinomatous tissue, but that association did not show a statistical relationship with histological risk assessment model [64].

\section{Conclusions}

Mast cells provoke much debate today regarding their role in a variety of physiological and pathological processes, including cancer. They act as gate keepers of the immune system and in turn respond to many signalling pathways, thus contributing to the process of carcinogenesis and metastasis. Many studies have revealed that mast cell counts were definitely increased along with tumour progression. New therapies targeting the mediators and receptors of mast cells play an important role in controlling the process of tumour progression and metastasis, thus favouring a good prognosis to the patient.

\section{The authors declare no conflict of interest.}

\section{References}

1. Marichal T, Tsai M, Galli SJ. Mast cells: potential positive and negative roles in tumor biology. Cancer Immunol Res 2013; 1: 269-79.

2. Di Girolamo N, Indoh I, Jackson N, et al. Human mast cell derived gelatinase B metalloproteinase 9 regulated by inflammatory cytokines: Role in cell migration. J Immunol 2006; 177: 2638-50.

3. Abbas AK, Litchman AH. Cellular and molecular immunology. 5th edition. Elsevier Saunders Publications, Philadelphia 2005; 27980, 436-37.
4. Michailidou EZ, Markopolos AK, Antoniades DZ. Mast cells and angiogenesis in oral malignant and premalignant lesions. Open Dent J 2008; 2: 126-32.

5. Machen TE, Rutten MJ, Ekblad EB. Histamine, CAMP, and activation of piglet gastric mucosa. Am J Physiol 1982; 242: 79-84.

6. Roitt I, Brostoff J, Male DK. Immunology. 6th ed. Mosby International Publications, Spain 2001; 2-61.

7. Cormack DH. Ham's histology. 9th ed. JB Lippincott company, Philadelphia 1987; 177-208.

8. Gilfillan AM, Rivera J. The tyrosine kinase network regulating mast cell activation. Immunol Rev 2009; 228: 149-69.

9. Urb M, Sheppard DC. The role of mast cells in the defence against pathogens. PLoS Pathog 2012; 8: e1002619. DOI: 10.1371/journal. ppat.1002619

10. Cheon EC, Khazaie K, Khan MW, et al. Mast cell 5-lipoxygenase activity promotes intestinal polyposis in APCDelta468 mice. Cancer Res 2011; 71: 1627-36.

11. Budzynski J, Klopocha M. Brain gut axis in pathogenesis of H. pylori. World J Gastroenterol 2014; 18: 5212-25.

12. Metcalfe D. Mast cells and mastocytosis. Blood 2008: 112; 257-67.

13. Gilfillan A, Tkaczyk C. Integrated signaling pathways for mast cell activation. Nat Rev Immunol 2006; 6: 218-30.

14. Marshall IS. Mast cell responses to pathogens. Nat Rev Immunol 2004; 4: 787-99.

15. Moreno AN, Jamur MC, Oliver C, Roque-Barreira MC. Mast cell degranulation induced by lectins: effect on neutrophil recruitment. Int Arch Allergy Immunol 2003; 132: 221-30.

16. Nilsson G, Johnell M, Hammer CH, Tiffany HL, Nilsson K, Metcalfe DD, Siegbahn A, Murphy PM. C3a and C5a are chemotoxins for human mast cells and act through distinct receptors via a pertussis toxin sensitive signal transduction pathway. J Immunol 1996; 157: 1693-98.

17. Weller CL, Collington SJ, Williams T, Lamb JR. Mat cells in health and disease. Clin Sci 2011; 120: 473-84.

18. Lee BP, Juvet SC, Zhang L. Prostaglandin E2 signalling through prostanoid receptor 2 impairs proliferative response of double negative regulatory cells. Int Immunopharmacol 2009; 9: 534-39.

19. Johansson A, Rudolfsson S, Hammarsten P, et al. Mast cells are novel independent prognostic markers in prostate cancer and represent a target for therapy. Am J Pathol. 2010; 177: 1031-41.

20. Ribatti D, Ennas MG, Vacca A, Ferreli F, Nico B, Orru S, Sirigu P. Tumor vascularity and tryptase-positive mast cells correlate with a poor prognosis in melanoma. Eur I Clin Invest 2003; 33: 420-5.

21. Strouch MJ, Cheon EC, Salabat MR, et al. Crosstalk between mast cells and pancreatic cancer cells contributes to pancreatic tumor progression. Clin Cancer Res 2010; 16: 2257-65.

22. Molica S, Vitelli G, Levato D, et al. Increased serum levels of matrix metalloproteinase-9 predict clinical outcome of patients with early B-cell chronic lymphocytic leukaemia. Eur I Haematol 2003; 70: 373-8.

23. Rajput AB, Turbin DA, Cheang MC, Voduc DK, Leung S, Gelmon KA, Gilks CB, Huntsman DG. Stromal mast cells in invasive breast cancer are a marker of favourable prognosis: a study of 4,444 cases. Breast Cancer Res Treat 2008; 107: 249-57.

24. Khazaie K, Blatner NR, Khan MW, et al. The significant role of mast cells in cancer. Cancer Metastasis Rev 2011; 30: 45-60.

25. Kalra M, Rao N, Nanda K, Rehman F, Girish KL, Tippu S, Arora A. The role of mast cells on angiogenesis in oral squamous cell carcinoma. Med Oral Patol Oral Cir Bucal 2012; 17: e190-6.

26. Zaidi M, Mallick A. A study on assessment of mast cells in oral squamous cell carcinoma. Ann Med Health Sci Res 2014; 4: 457-60.

27. Tanaka T, Kohno H, Suzuki R, Yamada Y, Sugie S, Mori H. A novel inflammation-related mouse colon carcinogenesis model induced by azoxymethane and dextran sodium sulfate. Cancer Sci 2003; 94: 965-73.

28. Soucek L, Lawlor ER, Soto D, Shchors K, Swigart LB, Evan GI. Mast cells are required for angiogenesis and macroscopic expansion of Myc-induced pancreatic islet tumors. Natural Medicines 2007; 13: 1211-8.

29. Nigrovic PA, Gray DH, Jones T, et al. Genetic inversion in mast cell-deficient mice interrupts corin and manifests as hematopoietic and cardiac aberrancy. Am J Pathol 2008; 173: 1693-701. 
30. Blair RJ, Meng H, Marchese MJ, Ren S, Schwartz LB, Tonnesen MG, Gruber BL.. Human mast cells stimulate vascular tube formation. Tryptase is a novel, potent angiogenic factor. J Clin Invest 1997; 99: 2691-700.

31. Johansson A, Rudolfsson S, Hammarsten P, et al. Mast cells are novel independent prognostic markers in prostate cancer and represent a target for therapy. Am J Pathol 2010; 177: 1031-41.

32. Chang DZ, Ma Y, Ji B, et al. Mast cells in tumor microenvironment promotes the in vivo growth of pancreatic ductal adenocarcinoma. Clin Cancer Res 2011; 15: 7015-23.

33. Flint N, Cove FL, Evans GS. Heparin stimulates the proliferation of intestinal epithelial cells in primary culture. J Cell Sci 1994; 107: 401-11.

34. Szlosarek P, Charles KA, Balkwill FR. Tumour necrosis factor-alpha as a tumour promoter. Eur J Cancer 2006; 42: 745-50.

35. Theoharides TC, Kempuraj D, Kourelis T, Manola A. Human mast cells stimulate activated T cells: Implications for multiple sclerosis. Ann N Y Acad Sci 2008; 1144: 74-82.

36. Marichal T, Tsai M, Galli SJ. Mast cells: potential positive and negative roles in tumor biology. Cancer Immunol Res 2013; 1: 269-79.

37. Walsh LJ, Trinchieri G, Waldorf HA, Whitaker D, Murphy GF. Human dermal mast cells contain and release tumor necrosis factor alpha, which induces endothelial leukocyte adhesion molecule 1. Proc Natl Acad Sci U S A 1991; 88: 4220-4

38. Norrby K. Mast cells and angiogenesis. APMIS 2002; 110: 355-71.

39. Ch'ng S, Wallis RA, Yuan L, Davis PF, Tan ST. Mast cells and cutaneous malignancies. Mod Pathol 2006; 19: 149-59.

40. Galli SJ, Tsai M, Wershil BK, Tam SY, Costa JJ. Regulation of mouse and human mast cell development, survival and function by stem cell factor, the ligand for the c-kit receptor. Int Arch Allergy Immunol 1995; 107: 51-53.

41. Gurish MF, Boyce JA. Mast cell growth, differentiation, and death Clin Rev Allergy Immunol 2002; 22: 107-18.

42. Grimbaldeston MA, Finlay-Jones JJ, Hart PH. Mast cells 464 Mast cells in lip squamous cell carcinoma in photodamaged skin: what is their role in skin cancer? Photochem Photobiol Sci 2006; 5: 177-83.

43. Walsh LJ. Mast cells and oral inflammation. Crit Rev Oral Biol Med 2003; 14: 188-98.

44. Sand L, Hilliges M, Larsson PA, Wallstron M, Hirsch JM. Effects of long-term administration of cancer-promoting substances on oral sub-epithelial mast cells in the rat. Anticancer Res 2002; 22: 2623-7.

45. Iamaroon A, Pongsiriwet S, Jittidecharaks S, Pattanaporn K, Prapayasatok S, Wanachantararak S. Increase of mast cells and tumor angiogenesis in oral squamous cell carcinoma. J Oral Pathol Med 2003; 32: 195-9.

46. Rojas IG, Martínez A, Pineda A, Spencer ML, Jiminez M, Rudolph MI. Characterization of mast cell subpopulations in lip cancer. J Oral Pathol Med 2005; 34: 268-273.

47. Telagi, N, Ahmed Mujib B, Kulkarni PG, Naik R. The master switch: Comparative study of mast cell in oral epithelial dysplasia, ora submucous fibrosis and oral squamous cells carcinoma and their association with inflammation and angiogenesis. J Oral Maxillofacial Pathol 2015; 19: 25-9.

48.Zaidi M, Mallick A. A Study on assessment of mast cells in oral squamous cell carcinoma. Ann Med Health Sci Res. 2014; 4 457-60.

49. Anuradha A, Kiran Kumar Naik B, Vijay Srinivas G, Ramisetty Sabitha Devi, Puneet HK. Incidence of mast cells in oral squamous cell carcinoma: A short study. J Oncol 2014; 2014: e614291.

50. Yadav A, Desai RS, Bhuta BA, Singh JS, Mehta R, Nehete AP. Altered immunohistochemical expression of mast cell tryptase and chymase in the pathogenesis of oral submucous fibrosis and malignant transformation of the overlying epithelium. PLoS One 2014; 9: e98719.

51. Pyziak L, Stasikowska-Kanicka O, Danilewicz M, Wągrowska-Danilewicz M. Immunohistochemical analysis of mast cell infiltrates and microvessel density in oral squamous cell carcinoma. Pol J Pathol 2013; 64: 276-80.

52. Gomes AP, Johann JE, Lovato GG, Ferreira AM. Comparative analysis of the mast cell density in normal oral mucosa, actinic cheilitis and lip squamous cell carcinoma. Braz Dent J 2008; 19: 186-9.
53. Kathuriya PT, Bartake AR, Palaskar SJ, Narang BR, Patil SS, Pawar RB. CD34 and mast cell analysis in normal oral mucosa and different grades of oral squamous cell carcinoma: a comparative study. J Clin Diagn Res 2015; 9: ZC61-4.

54. Cheema VS, Ramesh V, Balamurali PD. The relevance of mast cells in oral squamous cell carcinoma. J Clin Diagn Res 2012; 6: 1803-7.

55. Pujari R, Vidya N. Mast cell density in oral submucous fibrosis: a possible role in pathogenesis. Int J Health Sci (Qassim) 2013; 7: 23-9.

56. Parizi AC, Barbosa RL, Parizi JL, Nai GA. A comparison between the concentration of mast cells in squamous cell carcinomas of the skin and oral cavity. An Bras Dermatol 2010; 85: 811-8.

57. Jaafari-Ashkavandi Z, Khademi B, Akbari S, Malekzadeh M. Serum level of mast cell tryptase in patients with oral squamous cell carcinoma: lack of correlation with clinicopathologic factors. Asian Pac J Cancer Prev 2013; 14: 2955-8.

58. Sharma B, Sriram G, Saraswathi TR, Sivapathasundharam B. Immunohistochemical evaluation of mast cells and angiogenesis in oral squamous cell carcinoma. Indian J Dent Res 2010; 21: 260-5.

59. Kalra M, Rao N, Nanda K, Rehman F, Girish KL, Tippu S, Arora A. The role of mast cells on angiogenesis in oral squamous cell carcinoma. Med Oral Patol Oral Cir Bucal 2012; 17: e190-6.

60. Jahanshahi G, Sabaghian M. Comparative immunohistochemical analysis of angiogenesis and mast cell density in oral normal mucosa and squamous cell carcinoma. Dent Res J (Isfahan) 2012; 9: 8-12.

61. Ciurea R, Mărgăritescu C, Simionescu C, Stepan A, Ciurea M. VEGF and his R1 and R2 receptors expression in mast cells of oral squamous cells carcinomas and their involvement in tumoral angiogenesis. Rom J Morphol Embryol 2011; 52: 1227-32.

62. Mărgăritescu C, Pirici D, Simionescu C, Stepan A. The utility of CD44, CD117 and CD133 in identification of cancer stem cells (CSC) in oral squamous cell carcinomas (OSCC). Rom J Morphol Embryol 2011; 52: 985-93.

63. Souza Freitas V, de Andrade Santos PP, de Almeida Freitas R, Pereira Pinto L, de Souza LB. Mast cells and matrix metalloproteinase 9 expression in actinic cheilitis and lip squamous cell carcinoma. Oral Surg Oral Med Oral Pathol Oral Radiol Endod 2001; 112: 342-8.

64. Alaeddini M, Abachi H, Abbasi S, Shamshiri AR, Etemad-Moghadam S. Association of stromal factors with the histologic risk assessment model in oral squamous cell carcinoma. Appl Immunohistochem Mol Morphol 2017; 25: 129-33.

65. Tahir A, Nagi AH, Ullah E, Janjua OS. The role of mast cells and angiogenesis in well-differentiated oral squamous cell carcinoma. J Can Res Ther 2013; 9: 387-91.

\section{Address for correspondence}

\section{Arvind Babu Rajendra Santosh}

Oral and Maxillofacial Pathologist,

Lecturer and Research Coordinator - Dentistry Programme

Faculty of Medical Sciences

The University of the West Indies

Mona campus, Kingston 7

Jamaica, West Indies

e-mail: arvindbabu2001@gmail.com

Submitted: 4.05.2016

Accepted: 30.09.2016 